Bioscientia Medicina: Journal of Biomedicine \& Translational Research

Journal Homepage: www.bioscmed.com

\title{
Risk Factors for the Event of Pediculosis Capitis in the Baturaja Orphanage, South Sumatera, Indonesia
}

\section{Farhan Fadhillah1, Chairil Anwar ${ }^{2 *}$, Iche Andriyani Liberty ${ }^{3}$}

${ }^{1}$ Medical Education Study Program, Faculty of Medicine, Universitas Sriwijaya. Palembang. Indonesia ${ }^{2}$ Department of Parasitology Faculty of Medicine, Universits Sriwijaya, Palembang, Indonesia

${ }^{3}$ Department of Public Health Faculty of Medicine, Universitas Sriwijaya Palembang, Indonesia

\section{A R T I C L E I N F O \\ Keywords: \\ Pediculosis capitis \\ Risk factors \\ Orphanage \\ Baturaja \\ *Corresponding author: \\ Chairil Anwar \\ E-mail address: \\ Chairil53@fk.unsri.ac.id \\ All authors have reviewed and approved the final version of the manuscript.}

https://doi.org/10.32539/bsm.v5i9.354

\begin{abstract}
A B S T R A C T
Background: Pediculosis capitis is a disease of the scalp caused by infestation of Pediculus humanus capitis with symptoms such as itching and sensation of movement in the hair. The purpose of this study was to determine the risk factors and incidence of pediculosis capitis in the Baturaja orphanage. Methods: This research is an analytic observational study using a cross-sectional design with field and laboratory research. The population of this study were all children in the Baturaja orphanage who met the inclusion and exclusion criteria, as many as 172 children. All children present were taken as subjects. Data obtained by questionnaires, interviews and direct observation of the sample. Results: The results of this study showed the prevalence of pediculosis capitis in the Baturaja orphanage was $19.1 \%$. In this study, it was found that there was a significant relationship between age $(p=0.000)$, education $(p=0.000)$, the use of shared pillows $(p=0.000)$, the use of shared combs $(p=0.000)$, the use of shared towels $(p=0.000)$, knowledge $(p=0.000)$, attitudes and behavior $(\mathrm{p}=0.000)$ with the incidence of pediculosis capitis. Multivariate analysis showed that the most dominant risk factor for the incidence of pediculosis capitis in the Baturaja orphanage was age $(p=0.036)$, while behavior was a protective factor for the incidence of pediculosis capitis. Conclusion: There is a significant relationship between age, education, use of shared pillows, use of shared combs, use of shared towels, knowledge, attitudes, behavior with the incidence of pediculosis capitis. The most dominant risk factor for the incidence of pediculosis capitis in the Baturaja orphanage is age, while behavior is a protective factor for the incidence of pediculosis capitis.
\end{abstract}

\section{Introduction}

Pediculosis capitis is a disease caused by the parasite Pediculus humanus capitis. This parasite is an obligate parasite, which is a parasite that sucks human blood to survive. This parasite usually attacks children and spreads easily through crowded environments, such as dormitories and orphanages.1 Pediculosis capitis is considered a neglected disease and is still a health problem in poor and developing countries. 2 Research in Turkey in 2008 the prevalence of pediculosis capitis was $0.7-59 \%$, in Europe $0.48 \%$ -
22.4\%, in Australia 13\%, in America 3.6-61.4\%, and in South Africa $58.9 \%$ The study prevalence of pediculosis capitis in children aged 7-12 years in the Hulu Langat district of Malaysia was high (15.3\%). Most of the research was conducted on boys. The prevalence of pediculosis in girls (28.4\%) was significantly higher than in boys (3.7\%, $\mathrm{p}=0.001) .4$

Research on the incidence of pediculosis capitis at the X Palangka Raya Orphanage stated that there was no relationship between the level of knowledge and 
behavior of using shampoo on the incidence of pediculosis capitis. 5 Research on the risk factors for pediculosis capitis at the $\mathrm{X}$ Palembang Orphanage stated that from 43 foster children there were 30169.8 $\%)$, who suffer from pediculosis capitis with significant risk factors, namely age, gender, hair length, use of combs together and sleeping habits together. washing hair, using the bed together, the type and length of hair.7 Overcrowding in orphanages can trigger the incidence of pediculosis capitis because children share items. Research on pediculosis capitis in the Baturaja orphanage has never been done in this period, where the orphanage is overcrowded and the impact of pediculosis capitis on children is large because it can cause sleep disturbances and can affect children's cognitive function, therefore researchers are interested and make a title the relationship of risk factors for the incidence of pediculosis capitis to its occurrence in Baturaja.

\section{Methods}

This research is an observational analytic study using a cross sectional design with field and laboratory research. The population of this study were all 172 children in an orphanage in Baturaja. This research was conducted in five Baturaja orphanages, namely Mustika Orphanage, As-Saniyah Orphanage, Yusup Home Orphanage, Asyifa' Baturaja Orphanage, An-Nur Baturaja Orphanage. The inclusion criteria in this study were orphanage children who were willing to become respondents, by signing an informed consent (represented by a caregiver). The exclusion criteria in this study were orphans who did not have hair or were bald and orphaned children who were not present at the time of the study. The variables in this study were the risk factors for the incidence of pediculosis capitis, namely age, gender, education, hair characteristics (hair length, hair type and hair color), use of shared items (combs, pillows, towels), knowledge, attitudes and behavior.

\section{Results}

From 172 samples of orphanage children in
Baturaja, 33 children (19.1\%) suffered from pediculosis capitis. With the Chi Square test, it can be concluded that there is a significant relationship between the age of the respondents and the incidence of pediculosis capitis. Respondents with a younger age (5 -12 years) had a significant risk of 17.839 times suffering from pediculosis capitis compared to respondents aged 1319 years $(\mathrm{PR}=17.839$ (95\% CI 6.716 - 47.385); $\mathrm{p}=$ 0.000). There is no significant relationship between the sex of the respondent and the incidence of pediculosis capitis. (PR = $1.696(95 \%$ CI $0.751-3.832) ; \mathrm{p}=0.279)$. With the Chi Square test, it can be concluded that there is a significant relationship between education. With the Chi Square test, it can be concluded that there is a significant relationship between the respondent's education and the incidence of pediculosis capitis. Respondents with lower education (TK-SD) had a significant risk of 33.320 times suffering from pediculosis capitis compared to respondents with junior-high school education $(\mathrm{PR}=33.320$ (95\% CI $11.510-96.457) ; p=0.000)$. With the Chi Square test, it can be concluded that there is a significant relationship between the use of pillows together with the incidence of pediculosis capitis. Respondents who used shared pillows had a significant risk of 21.563 times suffering from pediculosis capitis compared to respondents who did not use shared pillows $(\mathrm{PR}=$ 21.563 (95\% CI 8.029 - 57.909); $\mathrm{p}=0.000)$. With the Fisher Exact test, it can be concluded that there is a significant relationship between the use of combs together with the incidence of pediculosis capitis. Respondents who used a shared comb had a significant risk of 13.615 times suffering from pediculosis capitis compared to respondents who did not use a shared comb (PR = 13.615 (95\% CI 3.136 - 59.109); $\mathrm{p}=0.000)$. There is a significant relationship between the use of towels together with the incidence of pediculosis capitis. Respondents who used shared towels had a significant risk of 8.819 times suffering from pediculosis capitis compared to respondents who did not share towels $(\mathrm{PR}=8.819$ (95\% CI $3.566-21.811)$; $\mathrm{p}=0.000)$. There is a non-significant relationship between the respondent's hair length and the incidence of pediculosis capitis. $(\mathrm{PR}=1.233(95 \% \mathrm{CI} 0.570-$ 
2.665); $\mathrm{p}=0.739)$. With the Fisher Exact test it can be concluded that there is a non-significant relationship between the respondent's hair color and the incidence of pediculosis capitis. $(\mathrm{PR}=4.313$ (95\% CI $0.263-$ $70.801) ; p=0.348)$. With the Chi Square test, it can be concluded that there is a non-significant relationship between the respondent's hair type and the incidence of pediculosis capitis. $(\mathrm{PR}=1.404$ (95\% CI $0.512-$ 3.847); $\mathrm{p}=0.699)$. There is a significant relationship between respondents' knowledge and the incidence of pediculosis capitis. $(\mathrm{PR}=33,060$ (95\% CI 10,664 102.491); $\mathrm{p}=0.000)$. With the Chi Square test, it can be concluded that there is a significant relationship between the attitude of the respondents and the incidence of pediculosis capitis. $(\mathrm{PR}=39.310$ (95\% CI $14.130-109.360) ; \mathrm{p}=0.000)$. There is a significant relationship between the behavior of respondents with the incidence of pediculosis capitis. (PR $=105.833$ (95\% CI 28.096-398.657); $\mathrm{p}=0.000)$. Multivariate analysis using the cox regression time constant test showed that the most dominant risk factor for the incidence of pediculosis capitis in the Baturaja orphanage was age $(\mathrm{PR}=15,769$ (95\% CI 1.193 - 208.457); $\mathrm{p}=0.036)$, while behavior was a protective factor in the incidence of pediculosis capitis.

Table 1. Distribution of the incidence of pediculosis capitis at the Baturaja Orphanage $(\mathrm{N}=172)$

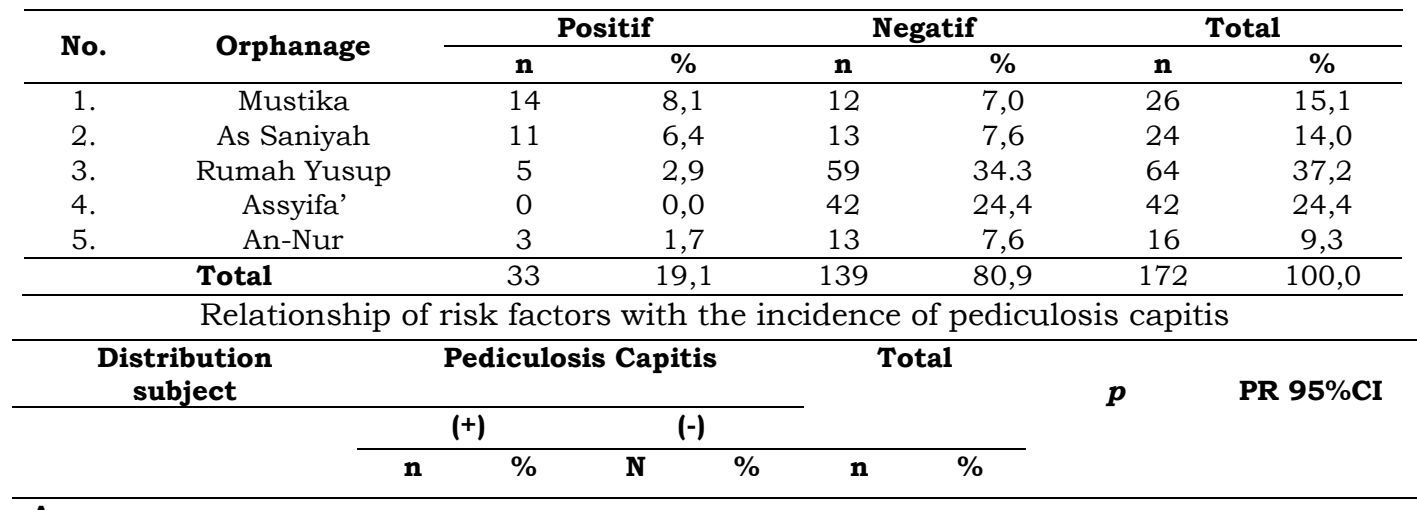

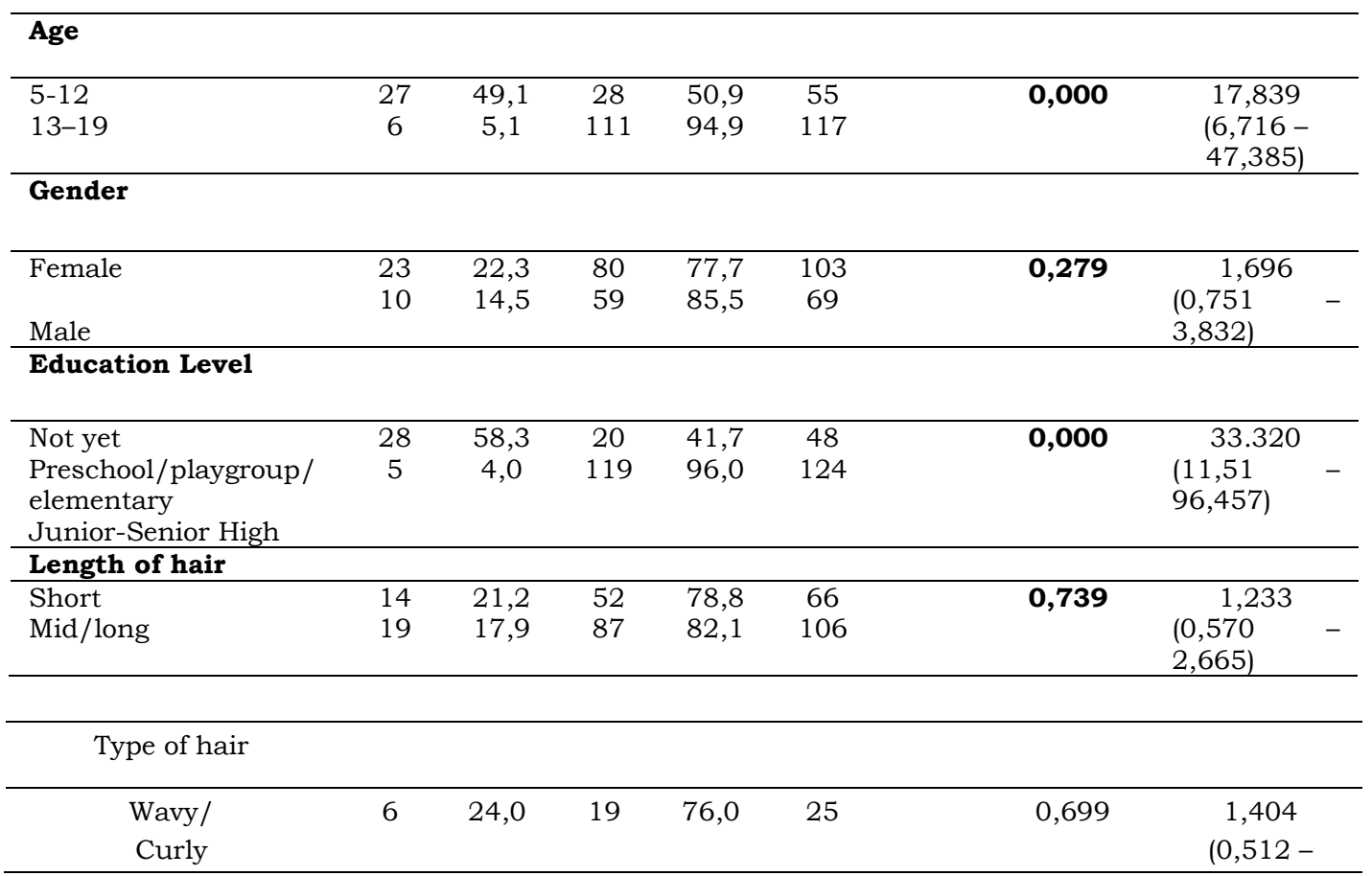




\begin{tabular}{|c|c|c|c|c|c|c|c|}
\hline Straight & 27 & 18,4 & 120 & 81,6 & 147 & & $3,847)$ \\
\hline \multicolumn{8}{|l|}{ Hair color } \\
\hline Not black & 1 & 50,0 & 1 & 50,0 & 2 & 0,348 & 4,313 \\
\hline Black & 32 & 18,8 & 138 & 81,2 & 170 & & $\begin{array}{l}(0,263- \\
70,801)\end{array}$ \\
\hline \multicolumn{8}{|c|}{ Use of shared pillow } \\
\hline Yes & 27 & 52,9 & 24 & 47,1 & 51 & 0,000 & 21,563 \\
\hline No & 6 & 5,0 & 115 & 95,0 & 121 & & $\begin{array}{l}(8,029- \\
57,909) \\
\end{array}$ \\
\hline \multicolumn{8}{|c|}{ Use of shared comb } \\
\hline Yes & 31 & 29,5 & 74 & 70,5 & 105 & 0,000 & 13,615 \\
\hline No & 2 & 3,0 & 65 & 97,0 & $67^{\circ}$ & & $\begin{array}{l}(3,136- \\
59,109)\end{array}$ \\
\hline \multicolumn{8}{|c|}{ Use of shared towel } \\
\hline Yes & 15 & 55,6 & 12 & 44,4 & 27 & 0,000 & 8,819 \\
\hline No & 18 & 12,4 & 127 & 87,6 & 145 & & $\begin{array}{l}(3,566- \\
21,811)\end{array}$ \\
\hline \multicolumn{8}{|c|}{ Level of knowledge } \\
\hline Good & 4 & 3,4 & 114 & 96,6 & 118 & 0,000 & 33,060 \\
\hline Poor & 29 & 53,7 & 25 & 46,3 & 54 & & $\begin{array}{c}(10,664- \\
102,491\end{array}$ \\
\hline \multicolumn{8}{|l|}{ Behaviour } \\
\hline Good & 7 & 5,2 & 127 & 94,8 & 134 & 0,000 & 39,310 \\
\hline Bad & 26 & 68,4 & 12 & 31,6 & 38 & & $\begin{array}{c}(14,130- \\
109,360)\end{array}$ \\
\hline \multicolumn{8}{|l|}{ Attitude } \\
\hline Good & 3 & 2,3 & 127 & 97,7 & 130 & 0,000 & 105,833 \\
\hline Bad & 30 & 71,4 & 12 & 28,6 & 42 & & $\begin{array}{l}(28,096- \\
398,657)\end{array}$ \\
\hline
\end{tabular}

Table 3. Dominant Risk Factor of Pediculosis Capitis

\begin{tabular}{ccccc}
\hline Variable & $\begin{array}{c}\text { Coeffisien } \\
\text { Regretion }(\beta)\end{array}$ & $\mathrm{p}$ & $\mathrm{PR}$ & CI95\% \\
\hline Age & 2,758 & 0,036 & 15,769 & $1,193-208,457$ \\
\hline Education & $-2,092$ & 0,171 & 0,123 & $0,006-2,472$ \\
\hline Use of shared pillow & $-1,144$ & 0,039 & 0,319 & $0,107-0,945$ \\
\hline Use of shared comb & $-1,529$ & 0,060 & 0,217 & $0,044-1,068$ \\
\hline Use of shared towel & -0.093 & 0,829 & 0,911 & $0,391-2,124$ \\
\hline Knowledge & -0.311 & 0,774 & 0,733 & $0,088-6,114$ \\
\hline Behaviour & 0,386 & 0,516 & 1,471 & $0,458-4,724$ \\
\hline Attitude & $-3,335$ & 0,002 & 0,036 & $0,004-0,296$ \\
\hline
\end{tabular}

\section{Discussion}

Based on research that has been conducted in five Baturaja orphanages with 172 orphanage children consisting of 69 boys and 103 girls, the incidence of pediculosis capitis was $19.1 \%$. The results of this study are similar to the research conducted in Hulu Langat,
Selangor, Malaysia in school children with the incidence of pediculosis capitis of $15.3 \% .4$ The study on the prevalence of pediculosis capitis in girls at the elementary school level in Southwest Iran in 20172018 showed the figure is $23.38 \%$ infected with pediculosis capitis. 8 Research conducted in Thailand found that the prevalence of pediculosis capitis was 
23.3\%.9 This is different from the results of the study by Dagne et al, (2019) in school children in the city of Woreta, located in Northwest Ethiopia. showed an incidence rate of $65.7 \% .10$ Research from Nurmatialila et.al regarding the incidence of pediculosis capitis in students of SDN 1 Tunggak, Grobogan Regency found that $35.3 \%$ of children suffered from pediculosis capitis. The incidence of pediculosis capitis in children at the Liga Da'wah orphanage in West Sumatra is $58 \% .11$ The incidence rate at the Baturaja orphanage can be influenced by some in the Baturaja orphanage that has been organized. The difference in incidence rates in the above study can be caused by different risk factors and the environment of the orphanage that has been studied, in one of the Baturaja orphanages there are children who have severe pediculosis capitis because there are many lice in the child's hair, and in other orphanages Pediculus humanus capitis eggs were found on examination of the hair of the orphanage children.

\section{Characteristics of Orphanage Children}

The results of this study were not much different from the study of Pediculus humanus capitis infestations in orphanages in the city of Pekanbaru. where the incidence of pediculosis capitis in the age group 6-12 years is more common. In contrast to the results of the study on pediculosis capitis among female students at PPMI Assalaam which stated that age did not have a significant relationship with the incidence of pediculosis capitis.12 Children aged 9-11 years were more at risk of developing pediculosis capitis compared to children aged 12 years and over. , this could be due to better personal hygiene in children aged 12 years and over. ${ }^{10}$ Females suffered from pediculosis capitis more than males in this study. Gender did not have a significant relationship in this study. In this study, it was found that lower levels of education (TK-SD) were more at risk than respondents with junior-high school.

\section{The relationship between the use of a comb together with pediculosis capitis}

Borrowing combs, owning their own combs and using combs alternately have a significant relationship with the incidence of pediculosis capitis. Respondents who use a shared comb have a significant risk of 13.615 times suffering from pediculosis capitis compared to respondents who do not use a shared comb. The use of shared combs can be an efficient mechanism in the transmission of pediculosis capitis

\section{Relationship between Pillow Use and Pediculosis Capitis}

This study shows that children who use shared pillows have a significant risk of 21.563 times suffering from pediculosis capitis compared to children who do not use shared pillows, and have a significant relationship to the incidence of pediculosis capitis. Research in Jordan on pediculosis capitis in elementary school children showed a significant relationship between the use of items such as combs, pillows, and scarves with other family members with the incidence of pediculosis capitis. Sharing goods together can increase the opportunity for physical contact so that there can be an increase in the opportunity for manifestations of pediculosis capitis. ${ }^{13}$

\section{The Relationship of Sharing Towels with Pediculosis Capitis}

In this study, there was a significant relationship between the use of towels together with the incidence of pediculosis capitis. Respondents who used shared towels had a significant risk of 8.819 times suffering from pediculosis capitis compared to respondents who did not share towels.

\section{Knowledge Relationship with Pediculosis Capitis}

In this study, it was found that there was a significant relationship between the respondent's knowledge and the incidence of pediculosis capitis. The study of the prevalence of pediculosis capitis and related factors in school children in the city of Woreta located in Northwest Ethiopia shows that knowledge is a predictor factor for the incidence of pediculosis capitis. Knowledge is an important predictor factor. Sufficient knowledge can produce a good attitude so that behavior can be carried out properly to deal with the incidence of pediculosis capitis. ${ }^{10}$ 


\section{Relationship between Attitude and Pediculosis Capitis}

In this study, there was a significant relationship between the attitude of the respondents and the incidence of pediculosis capitis. This study is the same as the results of the study of the relationship between the level of knowledge, attitudes and behavior of students and their severity with the incidence of pediculosis capitis in the Subulussalam Islamic boarding school, Plaju Palembang sub-district which stated that there was a significant relationship between respondents' attitudes and the incidence of pediculosis capitis. ${ }^{14}$

\section{Behavioral Relationship with Pediculosis Capitis}

In this study, there was a significant relationship between children's behavior and the incidence of pediculosis capitis. Research on the prevalence and risk factors of pediculosis capitis in the city of Sanadaj, Kurdistan province, Iran stated that the frequency of washing hair, washing hair habits and the habit of examining the head for lice are important factors in the prevention of pediculosis capitis. This study found a significant relationship between the incidence of pediculosis capitis and the habit of washing hair.

\section{Relationship of hair characteristics with Pediculosis Capitis}

In this study, there was no significant relationship between the respondent's hair length and the incidence of pediculosis capitis. The results of this study are different from research on female students at Pondok Pesantren Al-Hikmah Lampung where there is a significant relationship between hair length and the incidence of pediculosis capitis. 16

\section{Conclusion}

There are 33 (19.1\%) orphanage children suffering from pediculosis capitis. There is a significant relationship between age, education, use of shared pillows, use of shared combs, use of shared towels, knowledge, attitudes and behavior with the incidence of pediculosis capitis. The most dominant risk factor for the incidence of pediculosis capitis in the Baturaja orphanage is age, while behavior is a protective factor for the incidence of pediculosis capitis.

\section{Acknowledgement}

The authors would express their sincere gratitude to Mustika orphanage, As-saniyah orphanage, Rumah Yusup orphanage,Asyifa Baturaja orphanage, An-nur Baturaja orphanage who participated in this study.

\section{References}

1. Palagini L, Mosca M, Tani C, Gemignani A, Mauri M, Bombardieri S. Depression and systemic lupus erythematosus: a systematic review. Lupus 2013;22:409-16

2. Karol DE, Criscione-Schreiber LG, Lin M, Clowse ME. Depressive symptoms and associated factors in systemic lupus erythematosus. Psychosomatics 2013;54:443-50

3. Maneeton B, Maneeton N, Louthrenoo W. Prevalence and predictors of depression in patients with systemic lupus erythematosus: a cross-sectional study. Neuropsychiatr Dis Treat 2013;9:799-804

4. Schmeding A, Schneider M. Fatigue, health-related quality of life and other patient-reported outcomes in systemic lupus erythematosus. Best Pract Res Clin Rheumatol 2013;27:363-75

5. Zhang L, Fu T, Yin R, et al. Prevalensi depresi dan kecemasan dalam lupus erythematosus sistemik: tinjauan sistematis dan meta-analisis. BMC Psychiatry 2017; $17: 70$.

6. Illei GG, Shirota Y, Yarboro CH, Daruwalla J, Tackey E, Takada K, Fleisher T, Balow JE, Lipsky PE. 2010. Tocilizumab in systemic lupus erythematosus: data on safety, preliminary efficacy, and impact on circulating plasma cells from an openlabel phase I dosage-escalation study. Arthritis Rheum 62:542-552. 
7. Davis LS, Hutcheson J, Mohan C. The role of cytokines in the pathogenesis and treatment of systemic lupus erithematosus. $J$ Interf Cytok Res 2011;10:781-89

8. Ranjith G, Pariante C. Psychiatric toxicity of interferon-a:A model for understanding the etiology of major depression and chronic fatigue syndrome? In: Plotnikoff NP, Faith RE, Murgo AJ, Good RA (eds), Cytokine stress and immunity, 2nd edn Florida: CRC Press 2007.p349-58

9. Friedrich $\mathrm{C}$ et al. Association of IL-6, hypothalamus-pituitary-adrenal axis function, and depression in patients with cancer. Int Canc Ther 2010;9:270-75

10. Dowlati Y, Herrmann N, Swardfager W, Liu H, Sham L, Reim EK, et al. A meta-analysis of cytokines in major depression. Biol Psychiatry 2010;67: 446-57

11. Liu Y, Ho RC, Mak A. Interleukin (IL)-6, tumour necrosis factor alpha (TNF-a) and soluble interleukin-2 receptors (sIL-2R) are elevated in patients with major depressive disorder: a meta-analysis and metaregression. $\mathrm{J}$ Affect Disord. 2012;139(3):230-9

12. Tsuboi H, Sakakibara H, Minamida Y, Tsujiguchi H, Matsunaga M, Hara A, et al. Elevated levels of serum IL-17A in community-dwelling women with higher depressive symptoms. Behav Sci. 2018;8:17.

13. Emilia. Korelasi anatara kadar TNF-a serum dan gejala depresi pada penderita lupus eritematosus sistemik di poliklinik alergi imunologi penyakit dalam RSMH Palembang [disertasi]. [palembang]: universitas sriwijaya palembang; 2016.p83

14. Figueiredo MB, Cornaby C, Cortez A, et all. Depression and anxiety in systemic lupus erithematosus: The crosstalk between immunological, clinical, and psychosocial factors. Medicine 2018; 97:28
15. Figueiredo-Braga Margarida, Mota-Gracia Fernando, et al. Contemporary Challenges In Autoimmunity: Cytokines and Anxiety in Systemic Lupus Erythematosus (SLE) Patients not Receiving Antidepressant Medication. Ann. N.Y. Acad. Sci. 2009;1173: 286-291.

16. Kasjmir YI, Handono K, Wijaya LK. Rekomendasi perhimpunan rheumatologi Indonesia untuk diagnosis dan pengelolaan lupus eritematosus sistemik 2011: 1-47

17. Istiqomah, Annisa, Nova Kurniati, and Phey Liana. "Hubungan antara Tingkat Aktivitas Penyakit SLE dan Tingkat Depresi pada Penderita Lupus Eritematosus Sistemik di Persatuan Lupus Sumatera Selatan dan Poliklinik Ilmu Penyakit Dalam." Majalah Kedokteran Sriwijaya,2018, 50.4 : 185191.

18. Justiz V, Goyal A, Bansal P, et a. Systemic Lupus Erythematosus. [updated 2020 Nov 20]. In : StatPearls[Internet]. Treasure Island (FL): StatPearls Publishing; 2020 Jan.

19. Grigoriadis S, Robinson GE. Gender issues in depression. Annal of Clinical Psychiatry 2007;19(4):247-55.

20. National Institute for Health and Care Excellence (NICE). Clinical guideline. Depression in adults with a chronic physical health problem: recognition and management. 2020. Published 28 October 2009. ISBN:978-1-4731-2853-8

21. Fonseca R, Bernardes M, Terroso G,.de Sousa M, Figueiredo-Braga M. Silent burdens in disease: fatigue and depression in SLE. Autoimmune Diseases 2014, Article ID 790724 .

22. Speed SM, Jefsen HO, Borglum DA, Speed D, Ostergaard DS. Investigating the association between body fat and depression via Mendelian 
randomization.Translational Psychiatry (2019) 9:184.

23. Jacobs J, Korswagen L-A, Voskuy AE, Stek M, Dekker J, Bultink IEM. Depression in systemic lupus erythematosus, dependent on or independent of severity of disease. Lupus 2013;22:1462-9.

24. Zuadi, Rahmat. Hubungan Symptom Depresi Pada Pasien Dengan Penyakit Lupus Erimatosus SIstemik di Bagian Ilmu Penyakit Dalam RSUD DR. Zainoel Abidin Badan Aceh. ETD Unsyiah, 2015.

25. Speed SM, Jefsen HO, Borglum DA, Speed D, Ostergaard DS. Investigating the association between body fat and depression via Mendelian randomization.Translational Psychiatry (2019) 9:184.

26. Kwan A, Marzouk S, Ghanean $\mathrm{H}$ et al. Assessment of the psychometric properties of patient-reported outcomes of depression in systemic lupus erythematosus. Semin Arthritis Rheum 2019; 49:260-266.

27. Eldeiry, David, et al. Association between depression and anxiety with skin and musculoskeletal clinical phenotypes in systemic lupus erythematosus. Rheumatology, 2020.

28. Jordan, J., et al. Relationships among organ damage, social support, and depression in African American women with systemic lupus erythematosus. Lupus, 2019, 28.2: 253-260.

29. Gomez CR, Karavitis J, Palmer JL, et al. Research article: Interleukin-6 contributes to age -related alteration of cytokines production by macrophages. 2010. Article ID 475139 .

30. Safitri N, Sigit BR, Husain AA. Original article: Level of Interleukin-6 in obese people with and without insulin resistance. Acta interna journal of internal medicine. 2011.1(1): 21-23

31. Familia, A C; Yuliasih, Yuliasih; Rahmawati, Lita Diah. Correlation between serum IL-6 level and Th17/Treg ratio with Systemic Lupus Erythematosus Disease Activity. Biomolecular and Health Science Journal, 2019, 2.2: 107-112.

32. Thanadetsuntorn $\mathrm{C}$, Ngamjanyaporn $\mathrm{P}$, Setthaudom C, et al. the model of circulating immune complexes and interleukin-6 improves the prediction of disease activity in systemic lupus erythematosus. 2018.8:2620

33. Yuk CM, Park HJ, Kwon BI, Lah SJ, Chang J, Kim JY, et al. Basophil-derived IL-6 regulates TH17 cell differentiation and CD4 T cell immunity. Sci Rep. 2017; 7:41744.

34. Ding, Jianwen, et al. Serum interleukin-6 level is correlated with the disease activity of systemic lupus erythematosus; a metaanalysis. Clinics, 2020,75. 